\title{
Impact of ICT Usage in Travel and Tourism Industry in Madurai
}

\author{
J.Prabhu, K.Ravindran, S.Senthil Kumar
}

\begin{abstract}
In today's world information and communication technology is an essential part for any business to withstand among their competitors. Traveler's behavior totally changed with new technology refers to selecting tourist places and travel habits. This paper focused to find the impact of ICT in tourism and travel industry with special reference to Madurai. Around 70 respondents were surveyed and the paper represents the detailed analysis and findings.
\end{abstract}

Keywords: ICT, Madurai, Travel \& Tourism Industry, Impacts, Benefits.

\section{INTRODUCTION}

$\mathrm{T}$ ourism and hospitality industry is one of the slightest productive area in the economics of the most developed countries [1]. Gradually ICTs play a foremost role for the competiveness of tourism groups and destination

[2]. Evidence designates that effective application of information technology has turns out critical for the attractiveness and prosperity of tourism enterprises, since it has persuaded their ability to distinguish their offerings, as well as their manufacture and transport costs [3]. The tourism and hospitality is information intensive industry [4] with a quite long value chain [5] in which information plays vital role. Madurai is the fastest developing city in the field of Travel and Tourism, primarily it is known only temple and architecture but currently its developing the infrastructure like shopping arcade, Amusement park, multiplex theaters, world class Airport to attract visitors around the globe. By the way of using ICT in the field of Travel and Tourism sector also increasing in Madurai for time saving, avoid unwanted human errors as well as to improve the service quality. Similarly most of the travel and tourism sector people changed to digitalize their business to represent themselves around the world to attract more international travelers to our country. So this survey focuses the impact of ICT in the industry.

Revised Manuscript Received on December 20, 2019.

* Correspondence Author

J.Prabhu*, Department of Catering Science and Hotel Management, Kalasalingam Academy of Research \& Education, Krishnankoil, Tamilnadu, India.. Email: prabhu.j@klu.ac.in

K.Ravindran, Department of Management Studies, Kalasalingam Academy of Research \& Education, Krishnankoil, Tamilnadu, India.. Email: ravindran.k@klu.ac.in

S.Senthil kumar, Department of Catering Science and Hotel Management, Kalasalingam Academy of Research \& Education, Krishnankoil, Tamilnadu, India.. Email: ssenthilkumar@klu.ac.in

\section{LITERATURE REVIEW}

ICT refers to technologies that provide access to information through telecommunications. It is similar to Information Technology but focuses mainly on communication technologies. ICT allows organization to carry out their operations and strategic goals by interacting with stakeholders as well as managing their data and processes [6]. E-commerce is an commercial transactions conducted electronically on the internet. The introduction of E-Commerce and E-Business has increased possibilities and potential for all industries including tourism and hospitality [7]. Tourism is currently one of the fastest growing industries in the world [8] and as a service industry combining a range of products and services from other stakeholders, ecommerce and the adaptation of ICT offers great business potential. The combination of different activities and information in offering a tourism and hospitality product mean that specific product distribution can be catered for and that value adding chains can be established [9].

The internet has been a transformational technology playing a strategic role in the value chain in the industry and in service delivering process. Poon (1993) [10] remarked the adoption of such technologies marks a difference between the tradition tourism sector and new tourism industry as more customers adapt and adopt the new process, product and systems of tourism and hospitality delivery by the new technologies. This trend has continued with adoption for destinations in all areas of the world at different stages of tourism development [11].

The web and its similar developments was first adopted in the 1990s with the introduction of search engines help the consumers to evaluate their products with others. This bring a tremendous change on customers behaviour related to planning a trip, expectations, booking etc., and other related internet related development impact travel and tourism sector include online review, organizational website design and systems and adaptation of Smartphone technologies [12].

\section{RESULTS}

The researchers circulated a total of 100 questionnaires to the employees and the owners of the Travel and Tourism Sectors around Madurai for collecting the data. Out of 100 Questionnaire only 70 of them got the proper response from the respondent. In that 17 from the various category hotels, 16 of them are Travel Agents, 19 of them are lodging category and 18 respondents of Tour Operators. The total percentage of the respondent was $70 \%$. The questionnaire consists of 5 essential and 5 linear metric questions. 


\section{A. Level of ICT Usage in an organization}

The majority of the respondents agreed that they are using ICT in their organization shown in Figure 1. Almost $50 \%$ of the total respondents agreed that they are using ICT at high and very high level in their organization and only in the lodging category organizations are using very small amount of ICT in their operation.

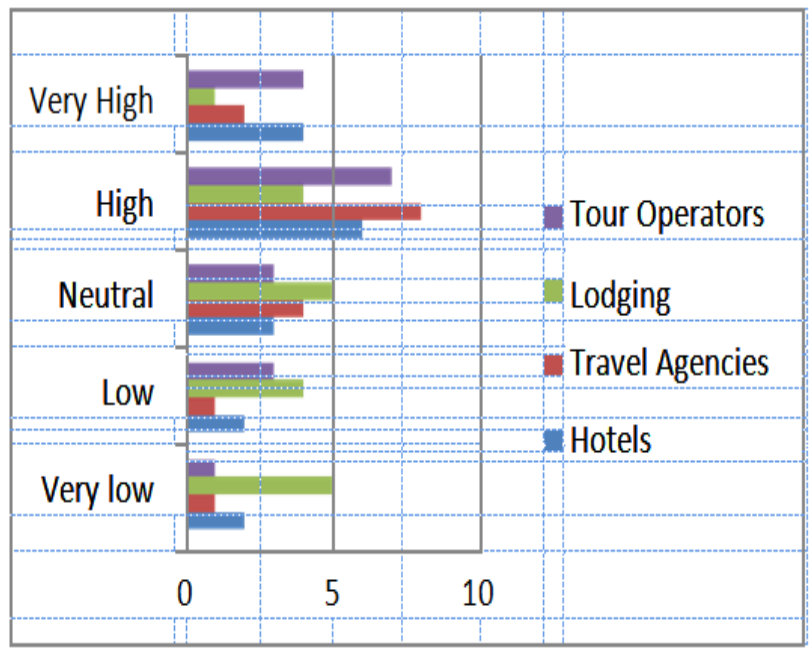

Figure 1 - Level of ICT Usage

B. Importance of ICT Usage in Travel and Tourism

According to the response from the participants it was about $47 \%$ of the respondents recommended the ICT tools in Travel and tourism organization and 25\% says Neutral , $14 \%$ respondents strongly agree and the least total of $05 \%$ and $07 \%$ respondents not recommended and strongly not recommended respectively shown in Figure 2

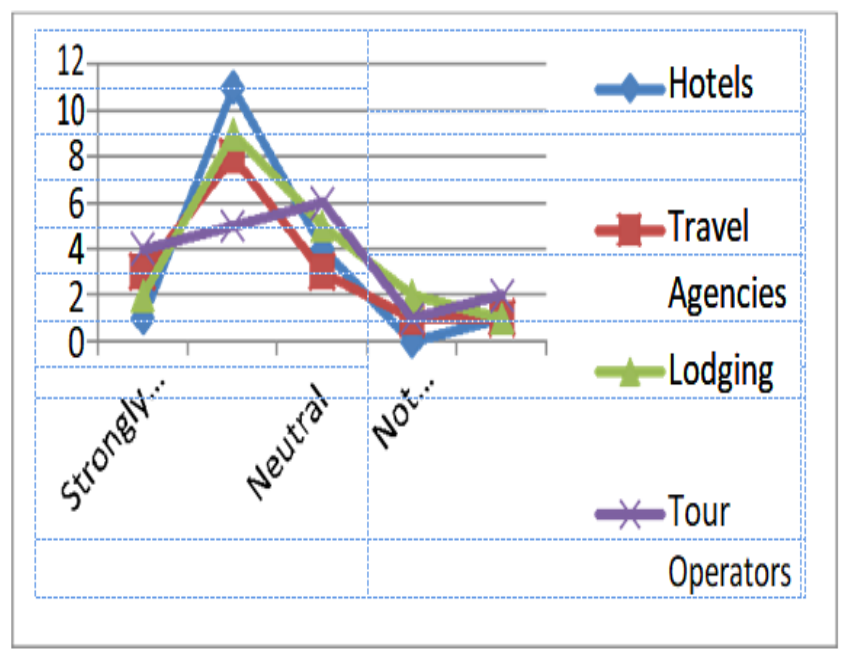

Figure 2 - Importance of ICT on Travel and Tourism Industry C. ICT Increases innovative practices in Tourism Industry

Figure 3 indicates that $28 \%$ of the respondents agree and $7 \%$ Strongly agree that the ICT increases the innovative practices in Travel and Tourism Industry and $17 \%$ are neutral and $12 \%$ of the respondents believe that ICT didn't do any innovative practices and 6\% are strongly disagree that ICT didn't do innovative practices.

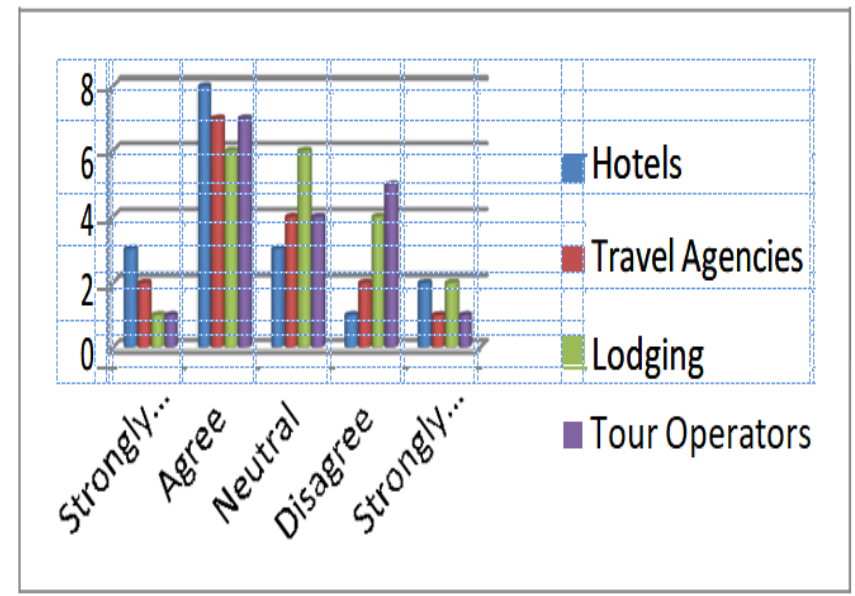

Figure 3 - ICT Increases innovative Practices D. ICT Helps in improving brand Image

According to Figure 4 Majority of the respondents believe that ICT plays an important role in improving the brand image of their business by the way of review their organization via online platform and in the same time very small amount of respondents around $13 \%$ are disagree nd strongly disagree that ICT doesn't help in improving their brand image around $19 \%$ of the respondents are neutral.

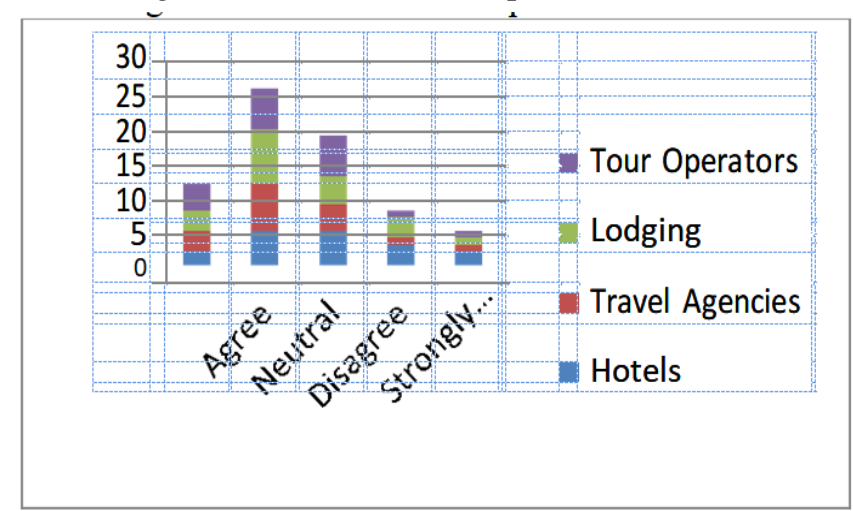

Figure 4 - ICT Improves brand Image

\section{E. ICT helps to meet the guest expectation}

As shown in Figure $533 \%$ and $25 \%$ of the participants agree an d Dis agree respectively that ICT helps to meet the guest expectation by means of feedback and reviews through online. And at the least amount of $(0.08 \%)$ only strongly disagree that ICT didn't meet the guest expectations.

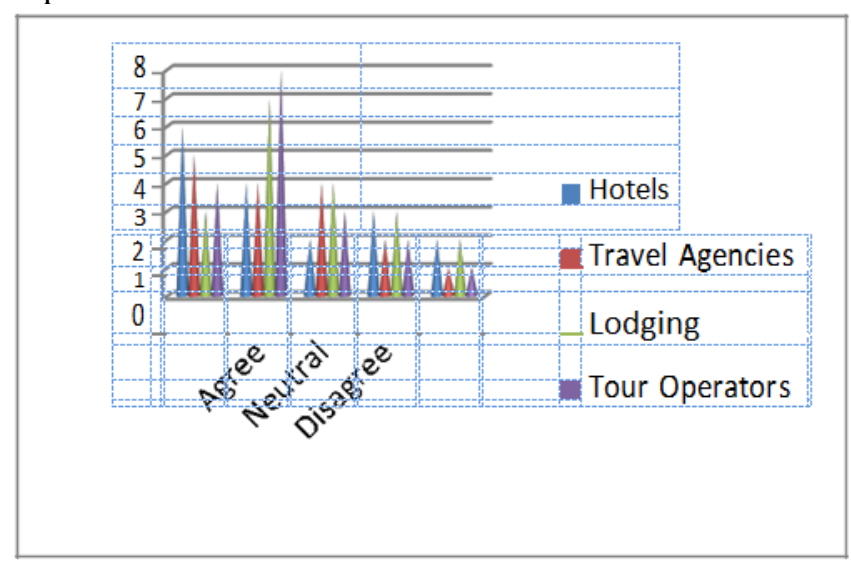

Figure 5 - ICT helps to meet the guest Expectations. 


\section{CONCLUSIONS}

After the careful analysis it has been observed that the usage of ICT in Travel and Tourism industry brings the high level of challenges among the industry. It has been revealed that most of the organizations aware and implemented ICT, most of the represents strongly agreed that it helps to know about the guest expectation, improve brand imaging as well as product development. During the survey we noticed that some of the difficulties of ICT in Madurai region the major concern was level of usage, it was not at the expected level some of the organization having the ICT but it was not up to date because of lack of knowledge as well as the survey area's economic level was at moderate. It has been expected that the TTDC has to come forward and take necessary steps to improve the quality of ICT usage in travel and tourism sector by the way of providing adequate training to the people in the sector for the betterment of inbound guest also to increase service quality.

\section{REFERENCES}

1. $\quad$ E. Scheidegger, "canthe sate promote innovation in tourism?Shouls it?," in Innovation and Growth in Tourism, Paris, 2006.

2. C. Coopers, Tourism Principles and Practices, UK: Pearson, 2005.

3. M. A. a. V. Soeriades, "E-Marketing and E commerce in the Tourism Industry: A Framework to developand implement Business Initiatives," in Tourism Today, 2004.

4. C. B. S. S. C. \&. B. J. Cox, "the role of user generated content in tourists travel planning behaviour," Journal of Hospitality Marketing and Management, pp. 743-764, 2009.

5. E. G. C. Stiakakis, "Drivers of a Tourism e-business Stratergy: The impact of Information and Communication Technologies.," in Operational Research, 2011.

6. J. Peppard, IT Stratergies for Business., London: Pitman Publising, 1993.

7. Z. Zhou, E-Commerce and information technology in hospitality and tourism., Newyork: Delmar Publishing, 2004.

8. M. a. U. Altin, "Economic Sentiment Indicator as a demand determinan in tourism: A Case of Turkey," Virginia Politechnic institute and State Universitiy, Blacksburg, VA, 2011.

9. H. a. K. Werthner, "Information technology and Tourism AChallanging Relationship.," Springer, 1999.

10. A. Poon, Tourism, Technology and Competitive Strategies, Oxford : $\mathrm{CAB}$ International.

11. R. a. L. H. Suomi, "Internet Adoption in Tourism Industry in china," in IFIP International Federationfor information Processing, 2010.

12. M. H. A. Khan, "The effect of ICT Application on the Tourism and Hospitality Industries in London," Socio Economic Challanges, no. 4 (2), pp. $60-68,2018$.

\section{AUTHORS' PROFILE}

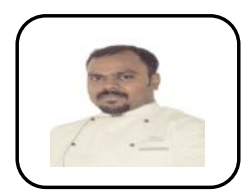

J.Prabhu, Completed B.Sc; in Hotel management in Sri Kaliswari College, Sivakasi. Completed M.B.A; in Tamilnadu Open University, Chennai. He poses 4 years industry experience and 9 years in Teaching Experience. Currently working as an Assistant Professor, Department of Catering Science \& Hotel Management, Kalasalingam University, Krishnan koil, Tamilnadu. prabhu.j@klu.ac.in

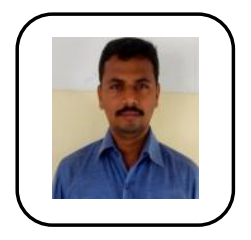

K. Ravindran, Completed graduation BA Economics in Chikkaiya Naickar Collage and post graduation MBA in Periyar University. Recently he has completed his Doctorate in periya university specialized in Marketing. He posses 2 years of industry experience and 8 years of teaching experience. He has published 2 papers in international journal.

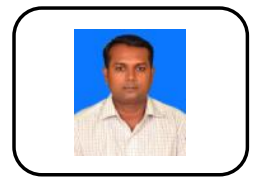

S.Senthilkumar, completed DHMCT at SIHMCT,Thuvakkudi and Post Graduation M.Sc; Hotel Management at Madurai Kamaraj University. Currently working as an Assistant Professor, Department of Catering Science \& Hotel Management, Kalasalingam University, Krishnan koil, Tamilnadu. jlpnos@gmail.com. 